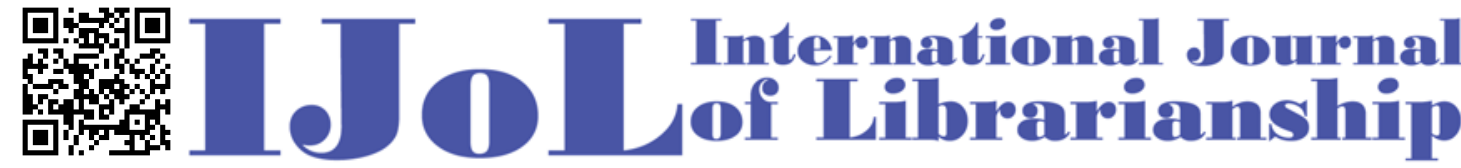

ISSN: 2474-3542 Journal homepage: http://journal.calaijol.org

\section{The Use of Social Media Instagram to Disseminate Sustainable Information}

\author{
Genilson Geraldo and Marli Dias de Souza Pinto
}

\begin{abstract}
:
Sustainable development does not depend only on changing the attitude of companies and government programs and projects, but it is essential that society is also sensitized and mobilized. Information sustainability is not a recent discussion, but it has been intensified in recent years and has become a focal point for scientific discussion. With technological advances, especially in the informational sphere, it is necessary that institutions that deal with information are in tune with their users in different environments. In this context, the use of social media by libraries is essential to relate to their audiences, who are increasingly immersed in digital culture. Currently, Instagram has more than 500 million users worldwide, making it a great informational and virtual engagement tool for library users. In this perspective, the profile @sustentabilidadeinformacional is presented in this study as a model for libraries to be more engaged with global objectives, according to actions developed and promoted by associative movements and library associations.
\end{abstract}

To cite this article:

Geraldo, G., \& Pinto, M.D.S. (2020). The use of social media Instagram to disseminate sustainable information. International Journal of Librarianship, 5(2), 4-12. https://doi.org/10.23974/ijol.2020.vol5.2.170

To submit your article to this journal:

Go to https://ojs.calaijol.org/index.php/ijol/about/submissions 


\title{
The Use of Social Media Instagram to Disseminate Sustainable Information
}

\author{
Genilson Geraldo and Marli Dias de Souza Pinto \\ Federal University of Santa Catarina, Florianópolis, SC, Brazil
}

\begin{abstract}
Sustainable development does not depend only on changing the attitude of companies and government programs and projects, but it is essential that society is also sensitized and mobilized. Information sustainability is not a recent discussion, but it has been intensified in recent years and has become a focal point for scientific discussion. With technological advances, especially in the informational sphere, it is necessary that institutions that deal with information are in tune with their users in different environments. In this context, the use of social media by libraries is essential to relate to their audiences, who are increasingly immersed in digital culture. Currently, Instagram has more than 500 million users worldwide, making it a great informational and virtual engagement tool for library users. In this perspective, the profile@sustentabilidadeinformacional is presented in this study as a model for libraries to be more engaged with global objectives, according to actions developed and promoted by associative movements and library associations.
\end{abstract}

Keywords: Sustainability, Informational Sustainability, Sustainable Information, Instagram, Social Media

\section{INFORMATIONAL SUSTAINABILITY}

In recent years, sustainability and sustainable development have become a topic of discussion in almost all human activities. In this sense, access to information can provide knowledge about what sustainability is and the benefits of sustainable development and can also provide access to knowledge of the true image of what happens and focus on what should be happening for the benefit of the planet and society. Sustainable development depends on changing companies and government programs and projects, but it is also essential that society is also sensitized and mobilized. There are sustainable practices that can be part of people's daily lives and, for that, it is essential that they have access to information about sustainability.

In addition, access to sustainable information can make society aware of the importance of developing efficient public policies. With this, make citizens participate in the elaboration and monitoring of efficient legislative projects and meet the global objectives of environmental socioeconomic well-being. In this sense, general debates and changes in individual and collective attitudes, involving associations and civil society, have in Information Science a relevant tool to develop new strategies for the use and 
dissemination of information in favor of global objectives and sustainable information technology innovations. As Lima (2018) pointed out, access to information on sustainability becomes a necessity, as it will be sustainable actions that will lead humanity to live in balance with the environment.

Therefore, it is necessary for humanity to continue its journey with sustainable development as a principle and planetary sustainability as a common objective. In view of this, as defended by Nolin (2010), informational sustainability has as its missions: to be in alignment with global objectives, in order to raise awareness and positively transform society's daily attitudes in the current context, aiming to guarantee the quality of life for future generations; and the development of sustainable information technologies.

In this perspective, the report "Our Common Future" (1987), prepared by the Brundtland Commission, drew the attention of humanity to the consequences of what was being done to the planet and to the need to search for a sustainable development model, in which, one of its main objectives was to provide informational means to deal with environmental issues more efficiently and to help define common notions and activities to successfully deal with problems of protection and improvement of the environment. Thus, it is important to emphasize that the use of information to assist in the dissemination, awareness and monitoring of sustainable development, has always been explicitly and implicitly exposed in the global agendas, plans, goals and objectives. A bulletin stood out in the creation of Agenda 21, also called Program 21, one of the main results of Rio-92, which had 40 chapters, divided into four possible ones, in the social, environmental and economical dimensions. Specifically, in section IV, chapters 35 and 40 , it dealt with the importance of science for sustainable development and the use of information for decision making, respectively (United Nations, 2020).

It is worth highlighting, in the Brazilian scientific scenario, the researcher Sarita Albagli (1995), who in her studies, in the 90s, had been discussing how the role of information and, in particular, of environmental information, in the context of the sustainable development, presenting an alternative to the global socio-economicenvironmental crisis. Similarly, in Spink's research (1999), when developing research to solve some crucial problems of the democratic information system, within an approach of basic needs for sustainable development.

Following Agenda 21 and anticipating the arrival of the new millennium, the UN General Assembly stressed that the year 2000 would be a special time to formulate a common project of global objectives approving the "Millennium Declaration" (United Nations, 2020). The declaration presented eight Millennium Development Goals (MDGs) to be achieved by the year 2015. MDG number 8 , specifically its objective 8 -E aims to make available new technologies, especially information technologies and communication. At the beginning of the 21 st century, the development of information and sustainability technologies was on the agenda of discussion of Information Science, with emphasis on the proposal of professor and researcher Dr. Jan Nolin, from the Swedish School of Library and Information Science in Borás (Sweden), which in 2010 suggested the use of information technologies for Sustainable Development and, at the same time, to support global objectives (NOLIN, 2010).

After several actions over the last few years promoted by the United Nations, such as the First United Nations Development Decade / 1960-1970; Stockholm 72; Brundtland Commission; Rio-92, Agenda 21, Millennium Development Goals, Rio + 20, and others, in September 2015, at the UN headquarters in New York City, a new agenda of global 
objectives was presented - the 2030Agenda. Therefore, in the area of Library and Information Science, studies and sustainable information practices were intensified, through promotional actions on the new UN agenda, carried out by professional information science organizations as International Federation of Library Associations and Institutions (IFLA), and nationally, by Brazilian Federation of Library Associations and Institutions (FEBAB).

The term "Informational Sustainability" can be seen as a way of relating the studies of Information Science with the global environmental socioeconomic objectives, in view of all these historical and conceptual points of information interrelated to sustainable development. The term Informational Sustainability refers to information resources that facilitate the integration, awareness and participation of the global objectives contributing to the strengthening of the process of transformation of society, according to the dimensions of sustainable development: environmental, economical and social.

Informational Sustainability can be a line of research in the area of Information Science, as well as a practical environmental and informational socio-economic tool for the area of Library Science. According to Nolin (2010), information science has two main missions: the first one is called "development of sustainable information", with the aim of connecting technology to sustainable development, with the main objective of making the production and use of information technologies in line with the objectives of sustainable development; the second is called "information for sustainable development", and aims to support the communicative aspects of integration, awareness and participation of society, in line with the ambitions of global, regional and local agendas, such as supporting the current 2030 Agenda and the Sustainable Development Goals, or support projects, campaigns around regional or local sustainability and sustainable development in the social, economic and environmental dimensions of Sustainable Development.

The social dimension aims at people's well-being and equal rights and opportunities; the economical dimension is not just profit and development, but what works for the prosperity of all citizens; and the environmental dimension aims to protect biodiversity (United Nations, 2020).

As stated by Geraldo and Pinto (2019), Meschede and Henkel (2019), there is evidence from Information Science researchers and representative entities, both national and international, who understand that the articulation of information represents an important strategic resource for the adoption of global agendas, however, these studies are still scarce. It is essential to remember that cognitive and attitudinal changes in general will modify the basic concepts of sustainability. Thus, Information Science can contribute to sustainable development, since information and knowledge play an important role in all contexts: from the individual to the organization.

It is important to emphasize that sustainability has to be thought and developed broadly and implemented from a global perspective, involving the entire planet in order to allow the benefit of one party not to be realized at the expense of the other's loss. Humanity depends on sustainability to maintain the quality of life of society and the planet and this consolidation of sustainability in society has to be based on information and knowledge, which create value for those who use it.

Informational sustainability as a line of research, discipline and object of study for Information Science, can raise questions about contemporary changes in sustainable technological innovations, aligned with global discussions, and may be in line with both the organizational well-being of governments, as well as, the well-being of human beings. 
Information sustainability is not a recent discussion, but it has been intensified in recent years and has become a focal point for scientific discussion. New ways of approaching informational problems on the topic and defining solutions are envisaged. In information science, the dissemination and use of sustainable information is an important way to make human beings reflect on their role in society and to commit to individual and collective actions in favor of improving life and the planet today and for future generations.

\section{THE USE OF INSTAGRAM TO DISSEMINATE SUSTAINABLE INFORMATION}

With technological advances, especially in the informational sphere, it is necessary that institutions that deal with information are in tune with their users in different environments. In this context, the use of social networks by libraries is essential to relate to their audiences, who are increasingly immersed in digital culture.

Currently, Instagram has more than 500 million users worldwide (Facebook Inc., 2020). According to information from Instagram's history, its history is short, but very successful and fast growing. Instagram was launched in 2010 by Kevin Systrom and Mike Krieger, both software engineers. On the same day of launch, the app became the most downloaded app on the Apple Store and, as of December of the same year, had an impressive 1 million users (Facebook Inc., 2020). In 2011, the company, which had only 6 employees, already had 10 million users. In 2012, after the long-awaited launch of the application in the Android version, Instagram was purchased by Facebook (2020).

According to the "Digital Report 2019", produced by "We Are Social" in partnership with a "Hootsuite", it pointed out that $66 \%$ of the Brazilian population is a user of social media, with Instagram being the fourth most used social media by Brazilians, with 69 million users in 2019, the highest level of engagement among social networks today (Digital In, 2019).

There is no correct and measurable number of profiles on Instagram that uses media to support sustainability and sustainable development. As well as the number of libraries, document centers, information centers and LIS professionals using social networks. However, currently, in the theme and defense of sustainability and sustainable development, one of the biggest profiles on Instagram is the @WWF (World Wide Fund for Nature) profile, with more than 2.5 million followers. The profile has the motto "Building a future in which human beings and nature can prosper." The environmental organization WWF International publishes beautiful photos of wild and endangered animal campaigns.

It is worth highlighting other profiles such as @SOS Mata Atlântica, with over 135 thousand followers - The Brazilian NGO promotes the conservation of the biological and cultural diversity of the Atlantic Forest and the ecosystems under its influence.

@ Greenpeace is an organization with over 3.5 million followers. It posts images of its actions, in addition to beautiful photos of the biome. Being a global organization whose main mission is to protect the environment, it puts its actions on Instagram that goes beyond creativity and daring, such as protests on ships, climbing skyscrapers, among other operations to draw the attention of the public.

Another highlight is the profile @ Fundação Grupo Boticário, with more than 65 thousand followers. Through its Natural Reserves, a Grupo Boticário Foundation conserves more than 11 thousand hectares of Atlantic Forest and Cerrado, the two most 
threatened biomes in Brazil. On Instagram, they post exuberant photos of animals and nature that inhabit the preserved region. The @Sea Shepherd-is the NGO focusing on the conservation of marine life. The group has more than 643,000 followers on Instagram. It uses direct action tactics to protect marine life, such as fighting Japanese whaling ships. Some photos are quite intense, like the killing of marine animals, but it shows the world what really happens in the oceans.

In the area of librarianship, it is possible to highlight some libraries that are present and active on Instagram, such as the New York Public Library (@nypl), with more than 455,000 followers. The NYPL profile features posts with aesthetically beautiful photos of books and events that take place at the site. The profile also places full-text books in the app's stories. Another highlight is the John Rylands Library (@thejohnrylands), with over 12,500 followers. Its architecture is beautiful and has a very Hogwarts vibe, the Instagram of this library in Manchester, England, posts many photos of its construction. Starfield Library (@ starfield.library), with more than 16,700 followers, located in Seoul, South Korea, it is a constant presence in several literary instagrams. The official profile is full of beautiful photos of her architecture and events that take place on the site; Library of Congress, which has approximately 77,000 followers. The profile presents events and the institution's rich collection. The British Library (@britishlibrary) stands out, which has more than 305,000 followers. Unlike other profiles of the genre, this one has speeches and interviews with curators and librarians, showing us a new world behind the doors of these institutions. In Brazil, the profile of the National Library Foundation (@ bibliotecanacional.br) has more than 57,000 followers, It presents posts with photos of books and events that take place on site.

However, until the conclusion of this study, no profiles of libraries were found on Instagram that presented posts aligned with global objectives or on the topic. Professional library associations, such as IFLA, American Library Association (ALA), FEBAB, have posts based on the International Advocacy Program (IAP), which aims to raise awareness and mobilize libraries and librarians to contribute to the dissemination and implementation of the 2030 Agenda.

\section{PROFILE@SUSTENTABILIDADEINFORMACIONAL}

Based on the scenario presented in the previous section, an Instagram profile @ sustentabilidadeinformacional is used for the dissemination of sustainable information, with the aim of informing, raising awareness, transforming and sensitizing users / followers, with this profile is the result of the actions developed by the research project entitled "United Nations Agenda 2030 in the IFLA/FEBAB's advocacy vision with libraries and librarians", under the coordination of $\mathrm{PhD}$. Marli Dias de Souza Pinto, from the Graduate Program in Information Science (PGCIN) at the Federal University of Santa Catarina.

Frequently regarding the referred project, libraries need to think about a new social paradigm, in which the research project promotes the rescue with a library centered on the organization and availability of systemic knowledge. The objective of the project consists of actions aligned with the International Advocacy Program (IAP) of the International Federation of Library Associations and Institutions (IFLA), to engage librarians at the local level, using the IAP, as in the defense of the inclusion of libraries in the Objectives and Sustainable Development Goals, available on the United Nations 
2030 Agenda, through the development of an awareness program with all librarians working in libraries.

It is believed that the UN Sustainable Development Goals (SDGs) in the rereading of the IFLA are not yet part of the context of all libraries, IFLA has since 2016 promoted materials, videos, newsletters on its website and social networks, seeking to raise awareness of libraries and librarians for this global cause. IFLA contributes to the visibility and importance of libraries and librarians, demonstrating that everyone's engagement in the IFLA International Advocacy Program (IAP).

The IAP program aims to subsidize libraries based on their promotion and support for the execution and implementation of 2030 Agenda by promoting actions that seek interests and influence the change in the behavior of the individuals, giving visibility to the importance of education and the library for sustainable development in all scenarios.

The Information Sustainability Instagram profile has the main objective of disseminating sustainable information. This is in line with the two missions defended by Nolin (2010): aligning the use and access to information to raise awareness, transforming and sensitizing the community of users of the importance of global objectives, such as the current 2030 Agenda and the Sustainable Development Goals; as well as providing information on sustainable information technologies, aligning with the main dimensions of sustainable, environmental, social and economic development.

The profile completed 1 year on Instagram in August 2020, with an average of more than 4,800 followers engaged in the cause of sustainability, sustainable development and global goals. The publications are daily and diverse, exploring the universe of sustainability, seeking to make its followers aware of the importance of a sustainable, inclusive life and equal rights for all.

According to the data collected by the information resources available on the Instagram application, the Instagram Sustainability of Information profile has a daily average of 438 accesses to the content; a daily average of 112 user interactions on the posted content; and an average of 233 daily likes on the posts made available. It is noticed that followers follow actively as profile posts, in which they interact with the content and share on their personal profiles.

As explained by Garcia and Sá (2017), the use of informational devices from the Internet allows information to flow quickly, simultaneously connecting people from different regions. The authors also point out that libraries and information units need to deal with new tools and technologies developed at an ever-increasing speed, with an increasingly broad, shared and dynamic universe of information, with new information demands and with users increasingly connected to social networking sites.

Seco, Santos and Bartalo (2016) explained that information science has considerably expanded its focus on studies of information users and has focused attention on virtual communities, seeking to understand the search and use of information in environments.

Thus, it can be seen that technologies are also the object of study in this interdisciplinary area. Seeing these technologies evolve, multiply quickly and help advanced studies on informational behavior will certainly provide users with access to an expanded number of sources and channels of information, which can offer new knowledge, awareness and mobilization for global causes, as the Sustainable Development Goals. 


\section{CONCLUSION}

It is important to use social media to reach library users. Social media allows users to express their opinions on topics presented, services and products offered by the library. With that, libraries can approach this niche of users, and thus, know the real interests and informational needs of the library's virtual audience.

Libraries can align their informational virtual services on their social networks with global objectives, as proposed and idealized by IFLA, with the 2030 Agenda International Advocacy Program.

Social media, such as Instagram, can be a great informational and advocacy tool for library users increasingly present in the digital environment. Instagram gained prominence for being a social media that has, since its inception, a massive adhesion of users. With this, libraries can develop advocating goals that take advantage of the nature and language of this application to keep their users informed about the actions and services of the libraries.

As a result, it is necessary for libraries to use social media to engage their users and communities in the virtual environment, and to use social media to make their followers aware of the importance of access to information on global causes of sustainability, social equality and human rights humans.

For the efficient use of social networking applications, it is necessary that in the strategic planning of the library's presence on social media, a responsible team is created to monitor and create engaging and informative content, since there is a need to use social media with assiduity and responsibility, providing posts, informational content about the actions, campaigns, updated events developed in the library, as well as informing followers of the actions of global objectives that the representative bodies of the libraries carry out.

This will allow libraries to raise awareness, transform, sensitize and mobilize users to topics of global interest, as well as demonstrate the library's interest in issues that are important for human socioeconomic and environmental well-being.

Finally, it highlights the importance of libraries, librarians, viewing social networks as an efficient means of approaching users. At the same time, align your information services with actions that address the causes and objectives that represent the profession's associative interests, like the projects promoted by IFLA.

The LIS professional organizations use their institutions, knowledge and research to promote, make available and disseminate information in favor of Sustainability and Sustainable Development, aiming at the current socio-economic environmental wellbeing, as well as ensuring that future generations can take advantage of natural, economic and consciously and equally.

The North American socio-environmentalist economist, Jeffrey Sachs (2017), points out that "[...] we have entered a new era, global society is interconnected as never seen before", and currently "we share the euphoria of new information age and also the fears of an environmental catastrophe on a global scale" (p. 13). Given this, "we are faced with new opportunities and also with new social, environmental, economic and informational risks" (p. 13).

For this reason, we can affirm that we have reached the "Era of Sustainable Development" and, the safe, reliable access to and efficient usability of information in 
alternative means of communication, other than just in the physical environment of the library, may be the more strategically efficient for the transformation of an egalitarian and sustainable societyThe proposal and missions of Information Sustainability can assist in this real and concrete path of Sustainable Development.

\section{References}

Albagli, S. (1995). Informação e desenvolvimento sustentável: novas questões para o século XXI. Rio de Janeiro. Retrieved DOI: 10.18225/ci.inf..v24i1.617.

Brundtland, G. H. (org.) (1987). Nosso futuro comum. Rio de Janeiro: FGV. Retrieved from

https://edisciplinas.usp.br/pluginfile.php $/ 4245128 / \mathrm{mod}$ resource $/$ content $/ 3 /$ Nosso $\% 2$ 0Futuro\%20Comum.pdf.

FEBAB (Federação Brasileira de Associações de Bibliotecários, Cientistas da Informação e Instituições) (2017). Retrieved from http://www.febab.org.br/.

Facebook Inc. (2020). About instagram. Retrieved from https://about.fb.com/

Garcia, I.O.D.S.; Sá, M. I. F. E. (2017, April-Jun.). Bibliotecas no instagram: Um estudo sobre o uso do aplicativo por unidades de informação. Prisma.com, 35(1). Retrieved from http://hdl.handle.net/20.500.11959/brapci/69658.

Geraldo, G. Pinto, M. D. S. (2019, April-Jun.). Percursos da ciência da informação e os objetivos do desenvolvimento sustentável da agenda 2030/ONU. Revista ACB: Biblioteconomia em Santa Catarina, 24(2). Retrieved from http://hdl.handle.net/20.500.11959/brapci/120776.

Lima, L. E. C. (2018). A sustentabilidade e sua realçai direta com a utilização indevida e desnecessária dos recursos naturais, com o consumismo, com a obsolescência programada e coma reciclagem. São Paulo. Retrieved from https://www.ecodebate.com.br/2018/08/08/a-sustentabilidade-e-sua-relacao-diretacom-a-utilizacao-indevida-e-desnecessaria-dos-recursos-naturais-artigo-de-luizeduardo-correa-lima/.

Meschede, C., Henkel, M. (2019). Information science research sustainable development. Proceedings of the Association for Information Science and Technology, 55(1). Retrieved fromhttps://www.researchgate.net/publication/330812968_Information_science rese arch and sustainable development

Nolin, J. (2010). Informação sustentável e ciência da informação. Information Research, 15(2). Retrieved from http://nformationR.net/ir/15-2/paper431.html

ONU (United Nations Organizations) (2015). Transformando nosso mundo: a 2030 Agenda para o Desenvolvimento Sustentável. Retrieved from http://www.br.undp.org/content/dam/brazil/docs/agenda2030/undp-br-Agenda2030completo-pt-br-2016.pdf.

ONUBR (Nações Unidas no Brasil) (2015). Objetivos do Desenvolvimento Sustentável. Retrieved from https://nacoesunidas.org/pos2015/ods4/.

Sachs, J. (2017). "The age of sustainable development". Columbia University Press.

Seco, L.F.C. (2016). Comportamento informacional e compartilhamento no instagram. Revista ACB: Biblioteconomia em Santa Catarina, 21(1). Retrieved from http://hdl.handle.net/20.500.11959/brapci/76475

Spink, A. (1999). Information science in sustainable development and deindustrialization. Information Research, 5(1). Retrieved from http://informationr.net/ir/5-1/paper65.html 


\section{About the authors}

Genilson Geraldo: Bachelor of Library Science from the Federal University of Santa Catarina; Specialization in Legal Document Management; Representative member of the International Federation of Library Associations and Institutions (IFLA) at the 58th Session of the United Nations Commission on Sustainable Social Development; Creator and manager of YouTube channel content and Profile on the social network Instagram (a)sustentabilidadeinformacional; $\mathrm{He}$ is currently a Master's student in Information Science at the Graduate Program in Information Science at the Federal University of Santa Catarina (PGCIN / UFSC). Develops research on Sustainability; Sustainable development; Informational Sustainability; Legal Information; Information management; Sustainable Development Goals; Green Marketing; Informational Quality in Sustainability reports.

Marli Dias De Souza Pinto (Pinto, M. D. S): Professor of the Postgraduate Program in Information Science and of the undergraduate courses at the Department of Information Science at the Federal University of Santa Catarina. $\mathrm{PhD}$ in Production Engineering; Master in Administration and graduated in Library Science (UFSC). Develops research on Informational Sustainability, Sustainable Development Goals, 2030 Agenda, International Advocacy Program, Studies of information users, Marketing in Information Units. 